\title{
Spermatological characters of Acanthobothrium crassicolle Wedl, 1855 (Tetraphyllidea, Onchobothriidae), a parasite of the common stingray Dasyatis pastinaca
}

\author{
Adji Mama Marigo ${ }^{1,2}$, Catarina Eira ${ }^{3,4}$, Cheikh Tidiane Bấ ${ }^{5}$ and Jordi Miquel|,2* \\ ${ }^{1}$ Laboratori de Parasitologia, Departament de Microbiologia i Parasitologia Sanitàries, Facultat de Farmàcia, Universitat de Barcelona, \\ Av. Joan XXIII, sn, E-08028 Barcelona, Spain; ${ }^{2}$ Institut de Recerca de la Biodiversitat, Facultat de Biologia, Universitat de Barcelona, \\ Av. Diagonal, 645, E-08028 Barcelona, Spain; ${ }^{3}$ CESAM \& Departamento de Biologia, Universidade de Aveiro, \\ Campus de Santiago 3810-193 Aveiro, Portugal; ${ }^{4}$ Sociedade Portuguesa de Vida Selvagem, Estação de Campo de Quiaios, \\ Apartado 16 EC Quiaios 3081-101 Figueira da Foz, Portugal; ${ }^{5}$ Département de Biologie Animale, \\ Université Cheikh Anta Diop de Dakar, Dakar, Senegal
}

\begin{abstract}
We describe the spermiogenesis process and the ultrastructural characters of the spermatozoon of Acanthobothrium crassicolle by means of transmission electron microscopy, including cytochemical analysis for glycogen. Spermiogenesis in A. crassicolle begins with the formation of the differentiation zone that contains two centrioles associated with striated rootlets and an intercentriolar body. The latter is formed by one electron-dense layer. The centrioles develop into two free flagella that first grow orthogonally to a median cytoplasmic process and then undergo flagellar rotation becoming parallel to that median cytoplasmic process. After flagellar rotation only one of the flagella completes its growth and both short and long flagella undergo proximodistal fusion with the median cytoplasmic process. In the final stages of spermiogenesis, the nucleus becomes filiform and migrates into the spermatid body. Later, the ring of arched membranes constricts and the spermatozoon is liberated from the residual cytoplasm. The ultrastructural organization of the spermatozoon of $A$. crassicolle follows the general pattern of spermatozoa of the other Tetraphyllidea-Onchobothriidae species, but exhibits some differences. It is filiform, tapered at both extremities and lacks mitochondrion. It contains two axonemes of unequal length showing the $9+$ " 1 " pattern of Trepaxonemata, a nucleus, parallel cortical microtubules and electron-dense granules of glycogen. The anterior extremity of the male gamete contains a single crested body surrounding a thin and long apical cone. This type of apical cone has never been described in a tetraphyllidean spermatozoon. Another particularity is the presence of a single electron-dense microtubule at the vertex of the crested body.
\end{abstract}

\section{Keywords}

Acanthobothrium crassicolle, Onchobothriidae, Tetraphyllidea, Cestoda, ultrastructure, spermiogenesis, spermatozoon

\section{Introduction}

The order Tetraphyllidea includes species that live essentially in the spiral valve of Elasmobranches (i.e., sharks and rays) but also in their sister group, the Holocephali (chimaeras). Euzet (1994) recognized eight families (Cathetocephalidae, Litobothriidae, Disculicipitidae, Prosobothriidae, Dioecotaeniidae, Onchobothriidae, Phyllobothriidae and Chimaerocestidae), all monogeneric except for the Phyllobothriidae and the Onchobothriidae. A phylogenetic analysis (Caira et al. 1999) revealed that tetraphyllideans are not monophyletic. In fact, while the family Onchobothriidae is a monophyletic group the family Phyllobothriidae is not monophyletic. Also according to the same analysis the uniloculate species are basal to the multiloculate, so the genus Acanthobothrium represents a basal onchobothriid lineage. Concerning the monogeneric families, the analysis of Caira et al. (1999) corroborates the recognition of the Litobothriidae although the validity and correct placement of Prosobothriidae, Dioecotaeniidae and Chimaerocestidae are not resolved for these authors. Finally, Caira et al. (1999) questioned whether the Cathetocephalidae and the Disculicipitidae represented two different families. More recent molecular data (Caira et al. 2005) corroborated the recognition of the order Cathetocephalidea erected by Schmidt and Beveridge (1990). According to the molecular analysis of Olson et al. (2001) the Tetraphyllidea are separated in four groups: the Rhinebothri- 

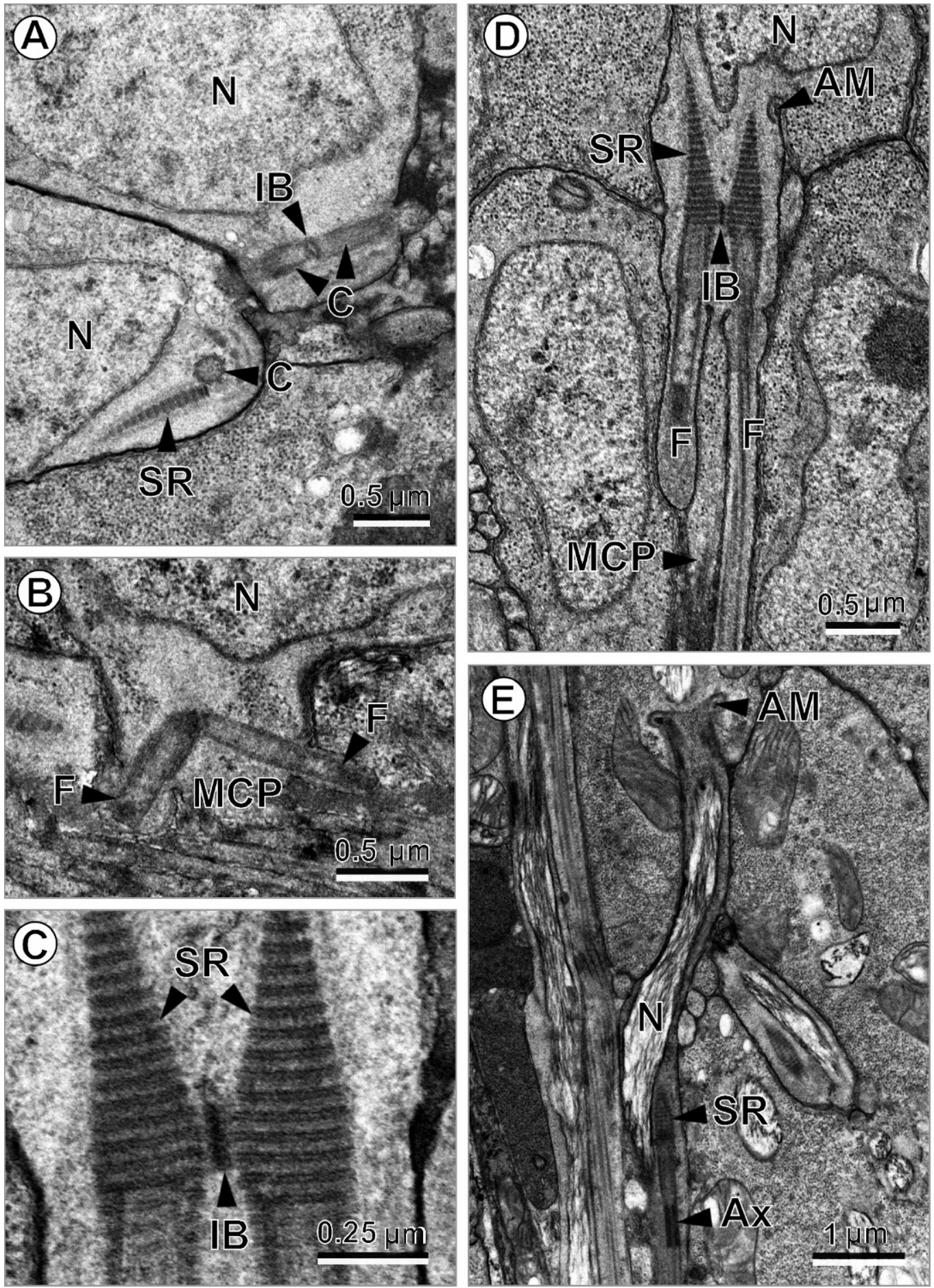

Fig. 1. TEM micrographs of the spermiogenesis of Acanthobothrium crassicolle. A. Longitudinal sections of the zone of differentiation showing the centrioles, the intercentriolar body and the striated rootlets. B. Longitudinal section of the zone of differentiation showing the flagellar rotation of the flagella towards the median cytoplasmic process. C. Detail of the intercentriolar body showing the single electrondense plate. D. Longitudinal section of the spermatid showing the parallel flagella, before the proximodistal fusion. E. Longitudinal section of a spermatid during the penetration of the nucleus and after the flagellar fusion showing the striated rootlets and one of the axonemes in an advanced stage of spermiogenesis. Abbreviations to all figures: AC - apical cone, AM - arched membranes, ASE - anterior spermatozoon extremity, $\mathrm{Ax}$ - axoneme, Ax 1 - first axoneme, Ax 2 - second axoneme, $\mathrm{C}$ - centrioles, $\mathrm{C} 1$ - first centriole, $\mathrm{C} 2$ - second centriole, $\mathrm{CB}$ - crested body, CM - cortical microtubules, D - doublets, F - flagellum, F1 - first flagellum, F2 - second flagellum, G - granules of glycogen, IB - intercentriolar body, MCP - median cytoplasmic process, $\mathrm{N}$ - nucleus, PM - plasma membrane, PSE - posterior spermatozoon extremity, $\mathrm{S}$ - singlets, $\mathrm{SR}$ - striated rootlets 
inae, the Phyllobothriidae, the Onchobothriidae and the genus Acanthobothrium. Moreover, it is interesting to remark the close relationships between Acanthobothrium and the Proteocephalidea (see Olson et al. 2001 and Waeschenbach et al. 2007).

In the last decades there is an important increase in the ultrastructural studies on spermatology of Platyhelminthes in general and cestodes in particular (see the review papers of Justine 1998, 2001; Levron et al. 2010). It is now widely accepted that ultrastructural spermatological characters contribute to a better understanding of relationships within the Platyhelminthes (Euzet et al. 1981; Justine 1991, 1995, 1998, 2001; Hoberg et al. 1997, 2001; Olson et al. 2001; Bruňanská 2010; Levron et al. 2010). To our knowledge, there are ultra- structural data on the spermiogenesis and/or spermatozoon of four onchobothriids. These are Acanthobothrium filicolle var. filicolle, Acanthobothrium filicolle var. benedeni, Onchobothrium uncinatum and Calliobothrium verticillatum (MokhtarMaamouri and Świderski 1975, Mokhtar-Maamouri 1982, Quilichini et al. 2007). Considering the phyllobothriids, there are data on another four species namely Phyllobothrium gracile, Trilocularia acanthiaevulgaris, Pseudanthobothrium hanseni and Phyllobothrium lactuca (Mokhtar-Maamouri 1979, MacKinnon and Burt 1984, Mahendrasingam et al. 1989, Sène et al. 1999).

In the present paper, ultrastructural characters of spermiogenesis and those of the mature spermatozoon of the onchobothriid Acanthobothrium crassicolle, an intestinal para-
(A)

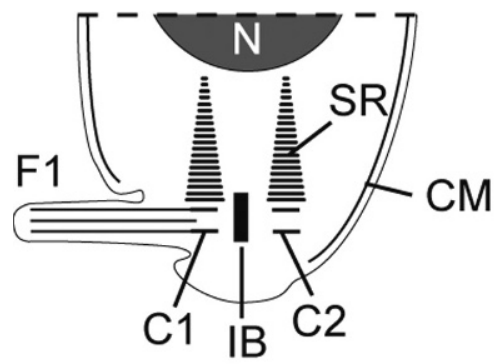

(B)

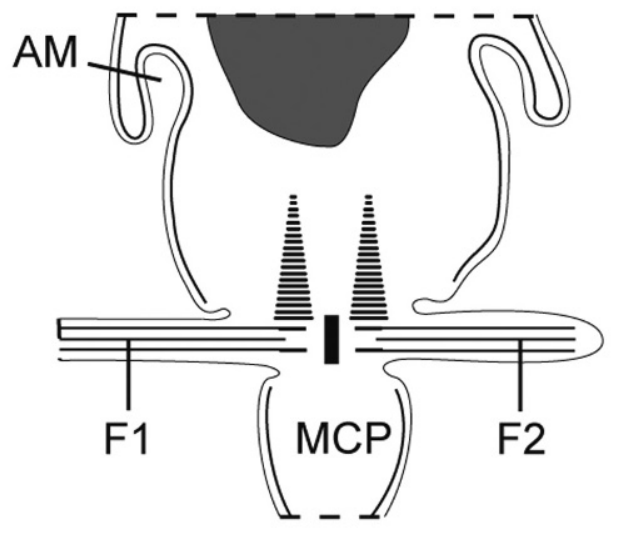

()

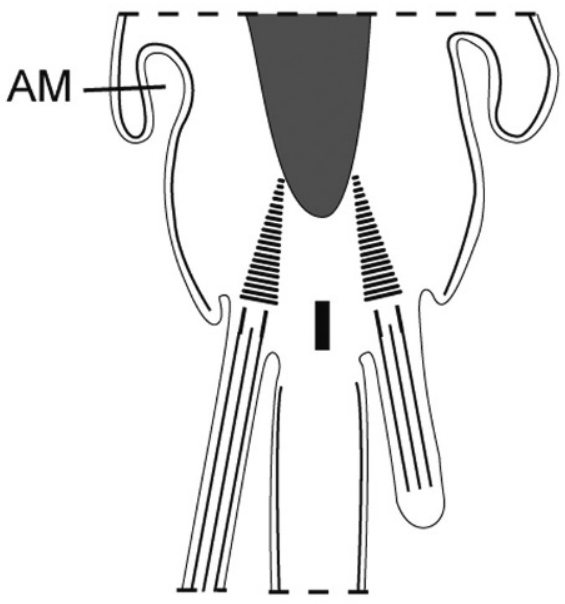

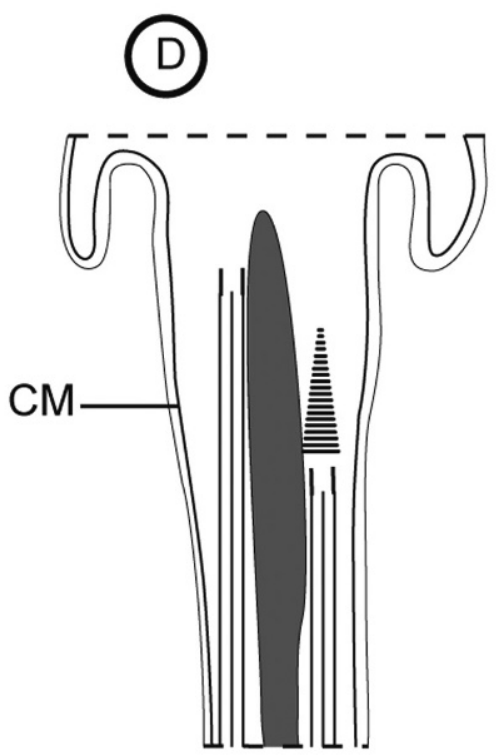

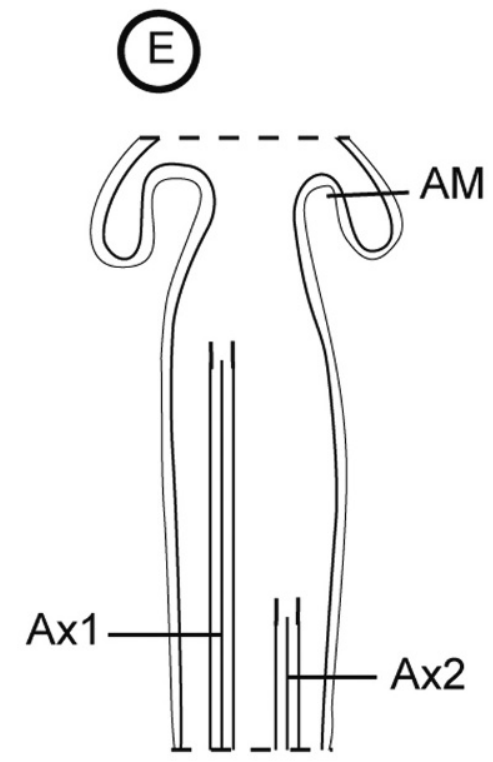

Fig. 2. Schematic drawing showing the main stages of spermiogenesis of Acanthobothrium crassicolle 

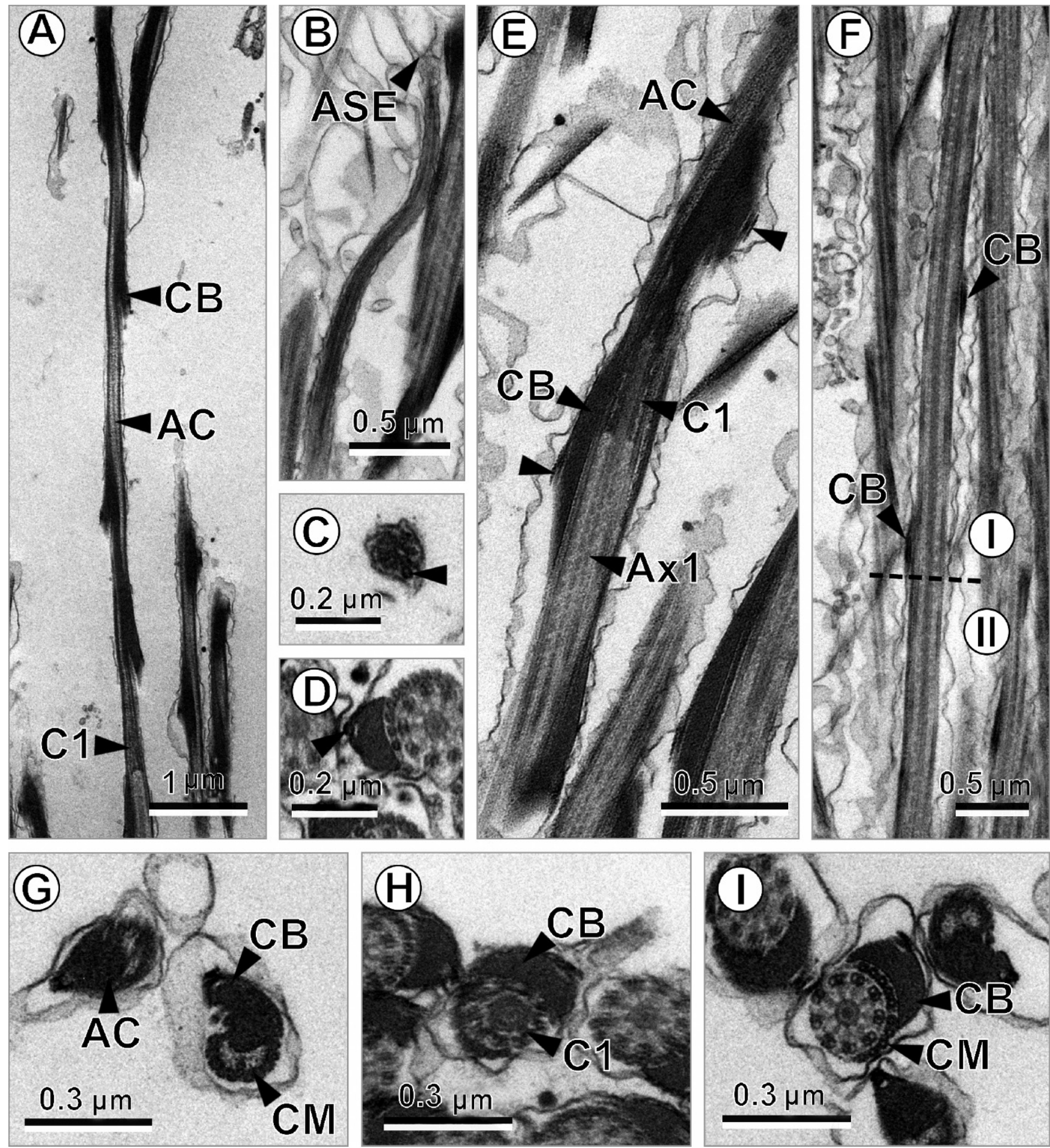

Fig. 3. TEM micrographs of the Region I of the spermatozoon of Acanthobothrium crassicolle. A. Longitudinal section showing the apical cone surrounded by the crested body. B. Detail of the anterior spermatozoon extremity in a longitudinal section. C. Cross-section at the level of the apical cone before the appearance of the crested body showing the presence of microtubules (arrowhead). D. Cross-section showing a detail of the crested body containing a cortical microtubule (arrowhead) in the exterior vertex. E. Longitudinal section at the level of the first centriole showing the apical cone, the crested body, the first axoneme and the cortical microtubule (arrowheads) in the exterior vertex of the crested body. F. Longitudinal section showing the transition area between Regions I and II. G. Two cross-sections at the level of the apical cone showing a row of electron-dense cortical microtubules and the crested body. H. Cross-section at the level of the first centriole. I. Crosssection showing the first axoneme and the arc-like row of 10 electron-dense cortical microtubules 

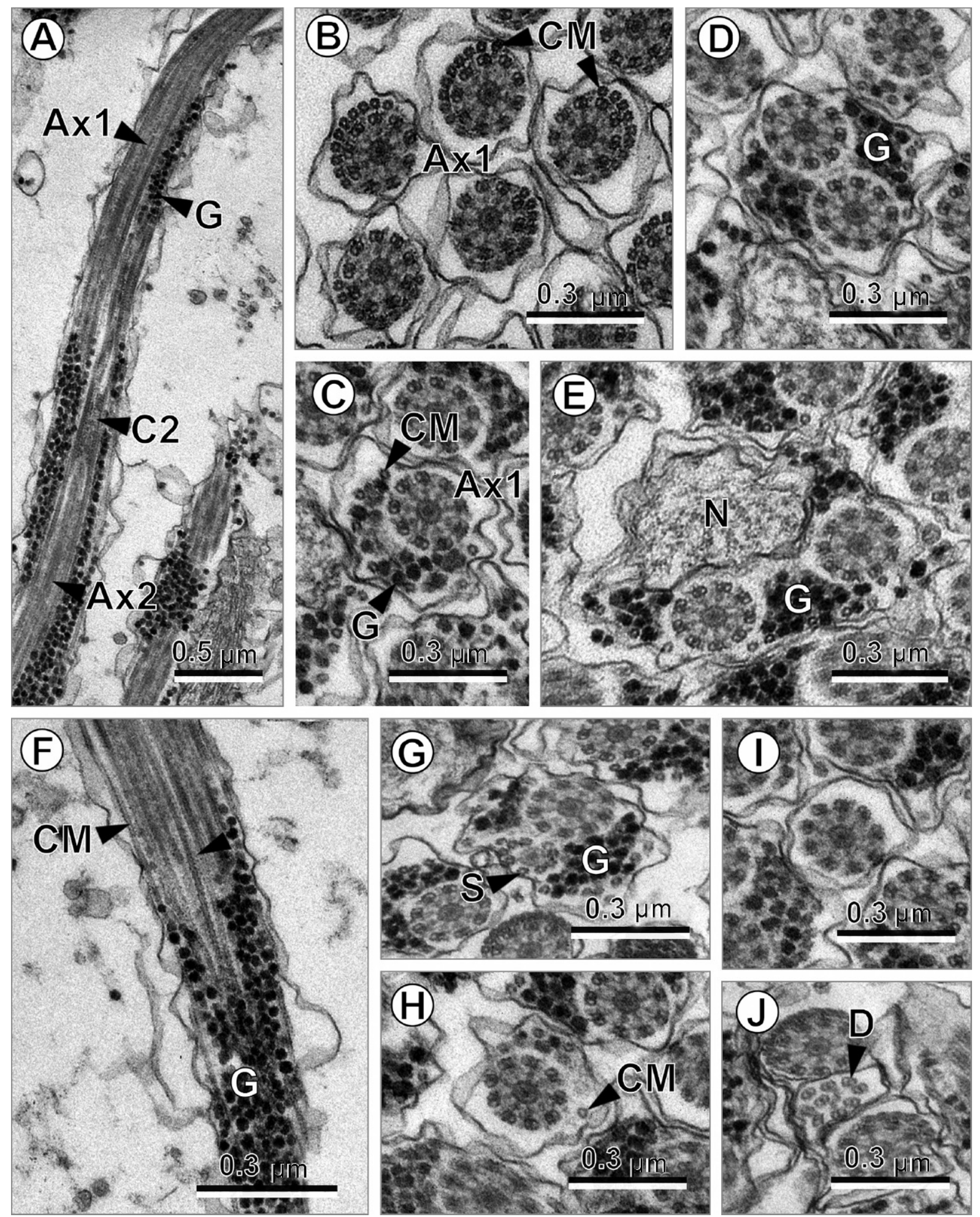

Fig. 4. TEM micrographs of the Regions II, III and IV of the spermatozoon of Acanthobothrium crassicolle. A. Longitudinal section of Region II showing the transition area between the region with one axoneme and the region with two axonemes. Remark the appearance of the second axoneme. B. Cross-sections of Region II showing the first axoneme coiled by the arc-like row of 10 electron-lucent cortical microtubules. C. Cross-section of Region II showing the appearance of granules of glycogen. D. Cross-section of Region II showing two axonemes. E. Cross-section of the nuclear region (Region III). F. Longitudinal section of Region IV showing the disorganization of the first axoneme (arrowhead). G. Cross-section of Region IV showing the disorganization of the first axoneme. H. Cross-section at the end of Region IV after the disappearance of the first axoneme. I. Cross-section of the posterior area of Region IV showing the axoneme surrounded by the plasma membrane. J. Cross-section at the posterior end of the spermatozoon showing the disorganisation of the last axoneme 
site of the common stingray (Dasyatis pastinaca) are compared with those of previously studied species belonging to the order Tetraphyllidea.

\section{Materials and methods}

Adult specimens of Acanthobothrium crassicolle were removed from the spiral valve of the common stingray Dasyatis pastinaca, caught off Sidi Mansour (Tunisia) in October 2007.

Living worms were cooled in $0.9 \% \mathrm{NaCl}$ solution and then the mature proglottids were processed for TEM examination: fixed at $4^{\circ} \mathrm{C}$ in $2.5 \%$ glutaraldehyde in $0.1 \mathrm{M}$ cacodylate buffer at $\mathrm{pH}=7.4$, for $2 \mathrm{~h}$, rinsed in the same buffer, postfixed at $4^{\circ} \mathrm{C}$ in $1 \%$ osmium tetroxide for $1 \mathrm{~h}$, rinsed in the same buffer, dehydratated in an ethanol series and propylene oxide, and finally embedded in Spurr. Ultrathin sections were cut using a Reichert-Jung Ultracut E ultramicrotome, placed on copper grids and double-stained with uranyl acetate and lead citrate. The grids were examined in a JEOL 1010 transmission electron microscope operated at an accelerating voltage of $80 \mathrm{kV}$.

The Thiéry (1967) technique was applied for detection of glycogen. Ultrathin sections, collected on gold grids, were treated in periodic acid, thiocarbohydrazide and silver proteinate (PA-TCH-SP) as follows: $30 \mathrm{~min}$ in 10\% of PA, rinsed in distilled water, $24 \mathrm{~h}$ in $\mathrm{TCH}$, rinsed in acetic solutions and distilled water, $30 \mathrm{~min}$ in $1 \% \mathrm{SP}$ in the dark, and rinsed in distilled water.

\section{Results}

\section{Spermiogenesis}

Spermiogenesis in A. crassicolle is illustrated in Figures 1A$\mathrm{E}$ and 2A-E. The beginning of spermiogenesis is characterized by the formation of small protrusions that appear at the periphery of the common cytoplasmic mass of spermatids. These areas, named zones of differentiation, are bordered by a field of cortical microtubules and contain two centrioles situated in the same plane (Fig. 1A). These centrioles are associated to striated rootlets and initially they are oriented perpendicularly to the intercentriolar body, which is formed by one electron-dense layer (Fig. 1A, C). The centrioles develop two flagella that soon initiate their flagellar rotation (Fig. 1B), becoming parallel to the median cytoplasmic process. One of the flagella completes its growth only in later stages of spermiogenesis after flagellar rotation (Fig. 1D). After the proximodistal fusion of the flagella with the median cytoplasmic process, a cone-like expansion of the nucleus extends towards the striated rootlets (Fig. 1D). The nucleus becomes filiform and initiates its migration pushing the striated rootlets beyond the ring of arched membranes (Fig. 1E). It is interesting to note that these striated rootlets are absent in the spermatozoon liberated after the constriction of the ring of arched membranes.

\section{Spermatozoon}

The ultrastructural organization of the mature spermatozoon of $A$. crassicolle is illustrated in Figures $3 \mathrm{~A}-\mathrm{I}, 4 \mathrm{~A}-\mathrm{J}, 5$ and $6 \mathrm{I}-\mathrm{IV}$. The male gamete is a filiform cell that lacks mitochondrion. From the anterior to posterior extremities, we have distinguished four regions (I to IV) with distinctive ultrastruc-

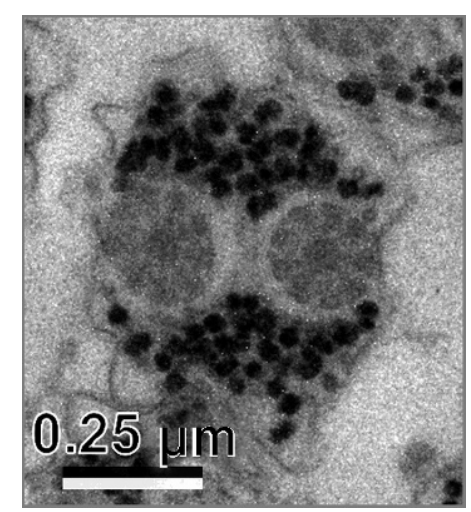

Fig. 5. Thiéry's staining to evidence the presence of glycogen tural characters.

Region I (Figs 3A-I, 6I) constitutes the anterior extremity of the mature spermatozoon. The main characteristics of this area are the presence of a long electron-dense apical cone and a single electron-dense helical crested body with a maximum thickness around $200 \mathrm{~nm}$ (Fig. 3A). The anterior part of this area begins with a thin region without crested body (Figs 3B, C) corresponding to the anterior spermatozoon extremity. Later, the helical crested body appears, surrounding a part of the apical cone and the portion of the cell containing the first part of the axoneme (Fig. 3A, D-I). An incomplete row of submembranous electron-dense and parallel cortical microtubules also surrounds partially the apical cone (Fig. 3G). In crosssections the crested body shows a triangular form with an electron-dense microtubule at the apex. This single microtubule appears in the anterior areas of the apical cone without crested body (Fig. 3C-E). The thickness of the crested body decreases progressively toward the end of region I (Fig. 3F). At the base of the apical cone, the centriole becomes visible (Fig. 3A, E, $\mathrm{H})$. The axoneme, of the $9+$ " 1 " trepaxonematan pattern, is partially bordered by an arc-like row of 10 parallel electron-dense cortical microtubules and by the crested body (Fig. 3I).

Region II (Figs 4A-D, 5, 6II) is characterised by the absence of the crested body. The anterior part of this region contains only one axoneme (Fig. 4A, B). Posteriorly, the second centriole is clearly visible showing the beginning of the second axoneme (Fig. 4A). In the area presenting only one axoneme the 10 cortical microtubules disposed in an arc-like arrangement become electron-lucent (Fig. 4B). Later, a large amount of glycogen granules appear forming a semi-circle around the axoneme (Fig. 4C). The granules of glycogen persist in the two-axoneme region but their disposition changes, becoming distributed into two groups on each side of the axonemes (Fig. 4C, D).

Region III (Figs 4E, 6III) corresponds to the nuclear area of the mature spermatozoon. The two axonemes, cortical microtubules and glycogen are still present. The nucleus is slightly electron-dense and exhibits an irregular shape (Fig. 4E).

Region IV (Figs 4F-J, 6IV) constitutes the postnuclear area of the mature spermatozoon. In the anterior zone of the region IV, one of the axonemes becomes disorganised (Fig. 4F, G): 


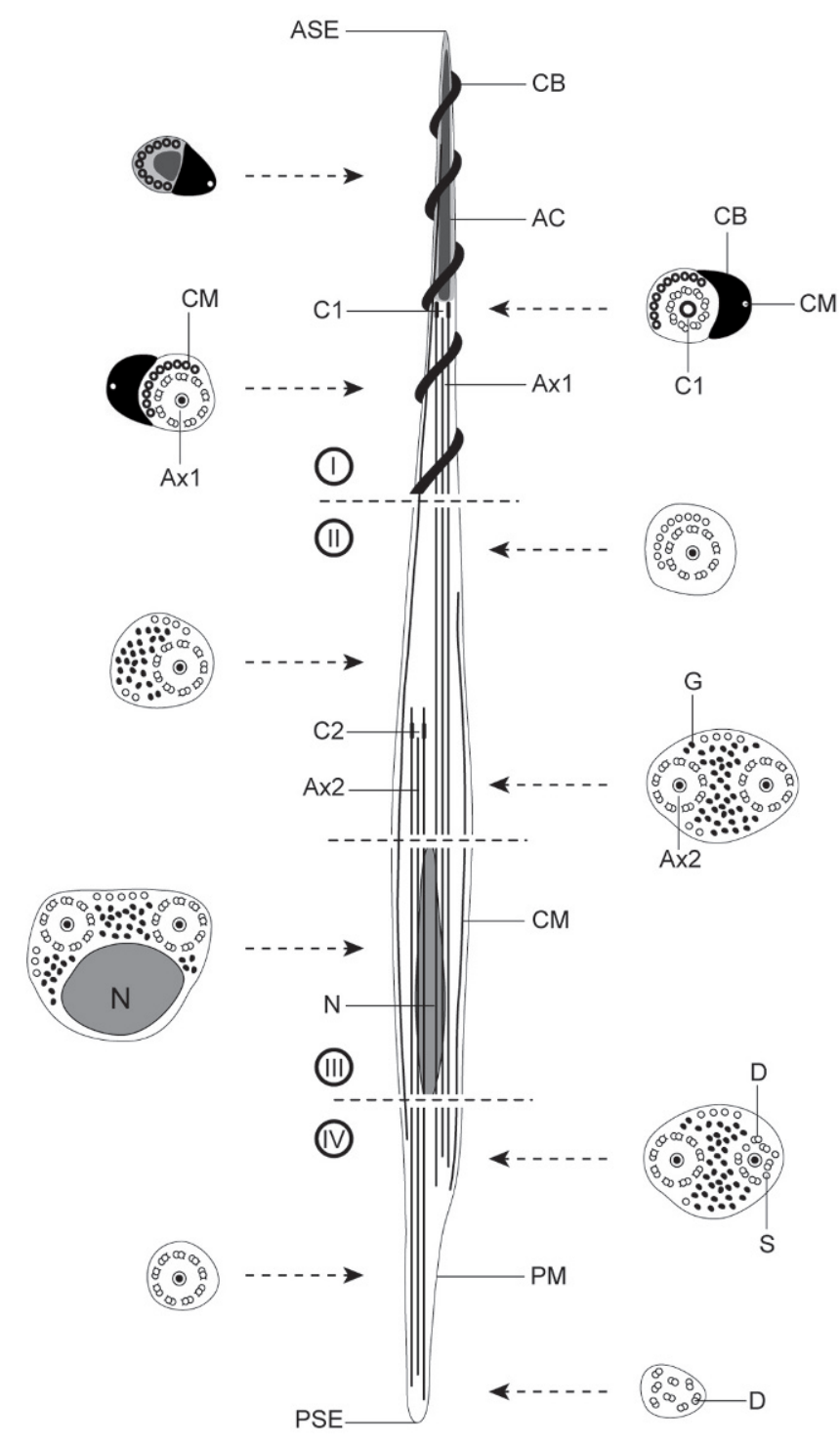

Fig. 6. Schematic drawing showing the ultrastructural organization of the mature spermatozoon of Acanthobothrium crassicolle

the central core subsists and the peripheral doublets are transformed into singlets (Fig. 4G). The disappearance of the first axoneme marks the gradual decrease in the amount of glycogen granules and cortical microtubules (Fig. 4H, I). The second axoneme progressively disorganizes toward the posterior extremity of the cell (Fig. 4J).

\section{Discussion}

\section{Spermiogenesis}

To date, there are ultrastructural data on the sperm of eight Tetraphyllidea, although data on spermiogenesis was available for only five species (two Phyllobothriidae and three Onchobothriidae): Phyllobothrium gracile, Phyllobothrium lac- tuca, Acanthobothrium filicolle var. filicolle, Acanthobothrium filicolle var. benedeni and Onchobothrium uncinatum (Mokhtar-Maamouri and Świderski 1975; Mokhtar-Maamouri 1979, 1982; Sène et al. 1999).

Ultrastructural studies have shown that tetraphyllideans have the particularity of possessing two patterns of spermiogenesis (I and II) according to Bâ and Marchand (1995). In fact, tetraphyllideans include Phyllobothriidae species whose spermatozoa contain one axoneme (except for P. lactuca and T. acanthiaevulgaris, Mahendrasingam et al. 1989, Sène et al. 1999) and Onchobothriidae species whose spermatozoa contain two axonemes (see Table I). In view of these ultrastructural data, the order Tetraphyllidea is certainly not monophyletic.

In addition, all the Onchobothriidae studied to date follow the type I spermiogenesis, with the presence of striated rootlets, intercentriolar body, flagellar rotation and proximodistal fusion, whereas in the Phyllobothriidae, P. gracile exhibits the type II spermiogenesis and $P$. lactuca exhibits the type I spermiogenesis. This variability in tetraphyllideans (see Justine 2001 and Levron et al. 2010) emphasises the need for additional data to confirm the pattern of spermiogenesis in this order. The type of spermiogenesis is important in the interpretation of relationships between the different orders of cestodes (Justine 1998, 2001; Levron et al. 2010).

In A. crassicolle, as in A. filicolle var. filicolle, the intercentriolar body consists of a single central electron-dense plate with a narrow lighter plate on each side, while in A. filicolle var. benedeni, P. lactuca and P. gracile there is a higher and variable number of intercentriolar body plates (see Table I). The absence and/or the strong reduction of the intercentriolar body could represent a synapomorphic character for these species (Hoberg et al. 1997, 1999, 2001; Justine 1998).

A particular characteristic found in the five Tetraphyllidea previously studied is the persistence of the striated rootlets in the body of the old spermatid after the proximodistal fusion (Mokhtar-Maamouri and Świderski 1975; Mokhtar-Maamouri 1979, 1982; Sène et al. 1999). This aspect is also evidenced in two Proteocephalidea namely Proteocephalus torulosus and Proteocephalus longicollis (Bruňanská et al. 2003a, 2004a). In the present study, striated rootlets were also observed in welldeveloped spermatids after the proximodistal fusion and during the migration of the nucleus.

\section{Spermatozoon}

Recently, on the basis of most important characters present in the spermatozoon, Levron et al. (2010) have been established seven types of spermatozoa in the eucestodes. These seven types are distinguished by the following characters: (1) the number of axonemes (one or two), (2) the parallel or spiralled pattern of cortical microtubules, (3) the parallel or spiralled pattern of the nucleus, (4) the absence or presence of crested bodies, (5) the absence or presence of a periaxonemal sheath, and (6) the absence or presence of intracytoplasmic walls. Brought to you by | Universidade de Aveiro Authenticated 
Table I. Spermatological characters in tetraphyllidean cestodes

\begin{tabular}{|c|c|c|c|c|c|c|c|c|c|}
\hline Families and species & \multicolumn{2}{|c|}{ Spermiogenesis } & \multicolumn{6}{|c|}{ Spermatozoon } & References \\
\hline \multicolumn{10}{|l|}{ Onchobothriidae } \\
\hline $\begin{array}{l}\text { Acanthobothrium filicolle } \\
\text { var. benedeni }\end{array}$ & I & 5 & II & & + & + & + & $\mathrm{Ax}$ & $\begin{array}{l}\text { Mokhtar-Maamouri and } \\
\text { Świderski (1975) }\end{array}$ \\
\hline $\begin{array}{l}\text { Acanthobothrium filicolle } \\
\text { var. filicolle }\end{array}$ & I & 1 & II & & + & + & + & Ax & Mokhtar-Maamouri (1982) \\
\hline Onchobothrium uncinatum & I & & II & & + & + & + & $\mathrm{Ax}$ & $\begin{array}{l}\text { Mokhtar-Maamouri and } \\
\text { Świderski (1975) }\end{array}$ \\
\hline \multicolumn{10}{|l|}{ Phyllobothriidae } \\
\hline Phyllobothrium gracile & II & 4 or 5 & IV & & + & + & + & $\mathrm{N}$ & Mokhtar-Maamouri (1979) \\
\hline Phyllobothrium lactuca & $\mathrm{I}$ & 3 & & & & & & & Sène et al. (1999) \\
\hline Pseudanthobothrium hanseni & & & IV & & + & + & & $\mathrm{Ax}$ & MacKinnon and Burt (1984) \\
\hline
\end{tabular}

AC - apical cone, ArcCM - arc-like row of cortical microtubules, CB - crested body, G - electron-dense granules, IB - intercentriolar body (number of plates), PSE - posterior spermatozoon extremity, + , presence of considered character. Spermiogenesis types are considered according to Bâ and Marchand (1995). Spermatozoa types are considered according to Levron et al. (2010).

Considering this classification, within the Tetraphyllidea there are two types of spermatozoon, the type II for the species belonging to the family Onchobothriidae and the type IV for the species of the family Phyllobothriidae. Type II spermatozoon exhibits two axonemes and crested bodies, and it is also characterized by the presence of parallel cortical microtubules and parallel nucleus. Type IV spermatozoon is distinguished from type II by the presence of one axoneme and by the spiralled pattern of the nucleus (see Levron et al. 2010). Acanthobothrium crassicolle presents a type II spermatozoon as all the Onchobothriidae tetraphyllideans studied to date.

In the tetraphyllidean cestodes, there is ultrastructural data on the spermatozoon of seven species: A. filicolle var. benedeni, A. filicolle var. filicolle, $C$. verticillatum, $O$. uncinatum, P. gracile, P. hanseni and T. acanthiaevulgaris (MokhtarMaamouri and Świderski 1975; Mokhtar-Maamouri 1979, 1982; MacKinnon and Burt 1984; Mahendrasingam et al. 1989 and Quilichini et al. 2007).

In tetraphyllideans, the apical cone was previously evidenced only in C. verticillatum (Quilichini et al. 2007). In A. crassicolle, the anterior spermatozoon extremity is also characterized by the presence of an electron-dense apical cone. This apical cone in A. crassicolle appears as a long electrondense structure surrounded by a coiled crested body. The crested body, described for the first time in the cestodes by Mokhtar-Maamouri and Świderski (1975), in A. filicolle benedeni, is present in all of the tetraphyllideans studied to date (see Table I). Bâ and Marchand (1995) and posteriorly Justine $(1998,2001)$ have proposed that the crested body always indicates the anterior extremity of the spermatozoon and constitutes a synapomorphy for the Eucestoda or for a part of the Eucestoda (Justine 2001).

The arc-like row of cortical microtubules present in all the studied Tetraphyllidea is located in the anterior region as oc- curs in other groups of cestodes. This is the case of four Caryophyllidea (Arafa and Hamada 2004, Gamil 2008, Bruňanská 2009 and Yoneva et al. 2011), three Spathebothriidea (MacKinnon and Burt 1984, Bruňanská et al. 2006, Bruňanská and Poddubnaya 2010), three Trypanorhyncha (Miquel and Świderski 2006, Miquel et al. 2007a, Marigo et al. 2011), one Bothriocephalidea (Bâ et al. 2007), three Diphyllobothridea (Justine 1986, Levron et al. 2006a, 2009), five Proteocephalidea (Bâ and Marchand 1994; Bruňanská et al. 2003a, b, 2004b, c) and two mesocestoidid Cyclophyllidea (Miquel et al. 1999, 2007b). The number of cortical microtubules forming the arc-like row in all these studies varies between three and eighteen depending on the level of section. However, in all Tetraphyllidea considered the number of microtubules forming the arc is 10 .

There are two types of cortical microtubules in the mature spermatozoon of $A$. crassicolle. The microtubules that form the arc-like row are observed in the anterior part of the sperm cell, presenting a hollow centre and being more electron-dense in comparison to the other type of microtubules. The transformation of microtubules from the first to the second type occurs at the end of the crested body region. The spermatozoon of the remaining studied tetraphyllideans presents an arc-like row of cortical microtubules, but unfortunately, the quality of TEM micrographs in these works are not sufficient to elucidate if two types of cortical microtubules really exists in the male gamete of these species (Mokhtar-Maamouri and Świderski 1975; Mokhtar-Maamouri 1979, 1982; MacKinnon and Burt 1984; Mahendrasingam et al. 1989 and Quilichini et al. 2007). Considering the remaining orders of the Eucestoda, two types of cortical microtubules have been reported in all the studied Bothriocephalidea (Świderski and MokhtarMaamouri 1980; Bruňanská et al. 2002, 2010; Levron et al. 2005, 2006b, c; Bâ et al. 2007; Šipková et al. 2010, 2011), in Brought to you by | Universidade de Aveiro 
one Diphyllobothriidea (Justine 1986), in three Trypanorhyncha (Miquel and Świderski 2006, Miquel et al. 2007a, Marigo et al. 2011), in four Proteocephalidea (Bruňanská et al. 2003a, b, 2004b, c) and in two mesocestoidids (Miquel et al. 1999, 2007b).

The mature spermatozoon of the five Onchobothriidae studied until now presents two axonemes of the $9+$ " 1 " trepaxonematan pattern (see Table I). However, in the Phyllobothriidae spermatozoa present one or two axonemes. In fact, Mahendrasingam et al. (1989) describe two axonemes in the spermatozoon of Trilocularia acanthiaevulgaris, while in the remaining studied Phyllobothriidae namely Phyllobothrium gracile (Mokhtar-Maamouri 1979) and Pseudanthobothrium hanseni (MacKinnon and Burt 1984) there is only one axoneme, according to the spermatozoon pattern assigned to this family (see Levron et al. 2010). Such differences evidenced within the same family may cause controversies for the phylogeny of this group because the presence of a single axoneme should be considered an evolved character (Euzet et al. 1981). Moreover, the number of axonemes in the mature spermatozoon constitutes one of the principal characters considered by Levron et al. (2010) for the distinction of the Eucestoda spermatozoa.

In what refers the close relationships between genus Acanthobothrium and the order Proteocephalidea postulated by several authors (Olson et al. 2001, Waeschenbach et al. 2007), the ultrastructure of spermiogenesis and the mature spermatozoon show great similitudes between these taxa when the most important characters are considered. However, these similitudes exist with all the Onchobothriidae and not only with the genus Acanthobothrium.

\section{Conclusion}

New spermatological data concerning the Tetraphyllidea are needed, particularly for the Phyllobothriidae family. Thus, the information available to date is insufficient to confirm the spermiogenesis and spermatozoon patterns attributed to this family. In what refers the Onchobothriidae, the present study has shown that this family may be a monophyletic group, because of the many analogies detected in the onchobothriid spermatozoon structure such as the type of spermatozoon, axoneme number, crested body, arc-like row of cortical microtubules and posterior tip. These observations indicate the necessity to study more tetraphyllidean species in order to provide a better knowledge of the phylogenetic relationships in this order.

Acknowledgements. We are thankful to Lassad Neifar and Hichem Kacem from the "Département des Sciences de la Vie de la Faculté des Sciences de Sfax" (Tunisia) for their valuable help in the fieldwork. We are also grateful to Núria Cortadellas and Almudena García from the "Servei de Microscòpia, Facultat de Medicina, Centre Científic i Tecnològic de la Universitat de Barcelona (CCiTUB)" for their support in the preparation of samples. This study was partially supported by the Spanish grants from the "Agencia Española de Cooperación Internacional para el Desarrollo (AECID)" of the "Ministerio de Asuntos Exteriores y de Cooperación (MAEC)" (no. A/2390/05 and no. A/6244/06). AM Marigo benefits from MAEC-AECID doctoral grants (no. 2009-10, 0000448124 and no. 2010-11, 0000538056).

\section{References}

Arafa S.Z., Hamada S.F. 2004. Spermatogenesis and sperm ultrastructure of the caryophyllidean cestode, Monobothrioides chalmersius (Woodland, 1924) Hunter, 1930. Egypt Journal of Zoology, 43, 49-70.

Bâ C.T., Bâ A., Marchand B. 2007. Ultrastructure of the spermatozoon of Bothriocephalus claviceps (Cestoda, Pseudophyllidea): a parasite of Anguilla anguilla (Fish, Teleostei). Parasitology Research, 101, 77-83. DOI: 10.1007/s00436006-0445-Z

Bâ C.T., Marchand B. 1994. Ultrastructure of the spermatozoon of Sandonella sandoni (Cestoda, Proteocephalidea, Sandonellinae). Invertebrate Reproduction and Development, 25, 9-17.

Bâ C.T., Marchand B. 1995. Spermiogenesis, spermatozoa and phyletic affinities in the Cestoda. Mémoires du Muséum National d'Histoire Naturelle, Paris, 166, 87-95.

Bruňanská M. 2009. Spermatological characters of the caryophyllidean cestodes Khawia sinensis Hsü, 1935, a carp parasite. Parasitology Research, 105, 1603-1610. DOI: 10.1007/s004 36-009-1599-2.

Bruňanská M. 2010. Recent insights into spermatozoa development and ultrastructure in the Eucestoda. In: (Eds. T. Lejeune and P. Delvaux) Human spermatozoa: maturation, capacitation and abnormalities. Nova Science Publishers Inc., New York, USA, 327-354.

Bruňanská M., Fagerholm H.-P., Nebesářová J., Kostič B. 2010. U1trastructure of the mature spermatozoon of Eubothrium rugosum (Batsch, 1786) with a re-assessment of the spermatozoon ultrastructure of Eubothrium crassum (Bloch, 1779) (Cestoda: Bothriocephalidea). Helminthologia, 47, 257-263. DOI: 10.2478/s11687-010-0040-9.

Bruňanská M., Nebesářová J., Scholz T. 2003a. Ultrastructure of the spermatozoon of the proteocephalidean cestode Proteocephalus torulosus (Batsch, 1786). Parasitology Research, 89, 345-351. DOI: 10.1007/s00436-002-0757-6.

Bruňanská M., Nebesáŕová J., Scholz T., Fagerholm H.-P. 2002. U1trastructure of the spermatozoon of the pseudophyllidean cestode Eubothrium crassum (Bloch, 1779). Parasitology Research, 88, 285-291. DOI: 10.1007/s00436-001-0532-0.

Bruňanská M., Poddubnaya L.G. 2010. Spermatological characters of the spathebothriidean tapeworm Didymobothrium rudolphii (Monticelli, 1890). Parasitology Research, 106, 1435-1442. DOI: $10.1007 / \mathrm{s} 00436-010-1822-1$.

Bruňanská M., Scholz T., Dezfuli B.S., Poddubnaya L.G. 2006. Spermiogenesis and sperm ultrastructure of Cyathocephalus truncatus (Pallas 1781) Kessler 1868 (Cestoda: Spathebothriidea). Journal of Parasitology, 92, 884-892. DOI: 10. 1645/GE-718R1.1.

Bruňanská M., Scholz T., Ibraheem M.H. 2004b. Ultrastructural characters of the spermatozoon of the cestode Corallobothrium solidum Fritsch, 1886 (Cestoda: Proteocephalidea), a parasite of the electric catfish Malapterurus electricus. Parasitology Research, 94, 421-426. DOI: 10.1007/s00436-004-1236-z.

Bruňanská M., Scholz T., Ibraheem M.H. 2004c. Ultrastructural particularities of the spermatozoon of the cestode Electrotaenia malopteruri (Fritsch, 1886) (Proteocephalidae: Gangesiinae), a parasite of Malapterurus electricus (Siluriformes: MaBrought to you by | Universidade de Aveiro Authenticated 
lapteruridae) from the river Nile, Egypt. Parasitology Research, 93, 114-120. DOI: 10.1007/s00436-004-1109-5.

Bruňanská M., Scholz T., Nebesářová J. 2003b. Reinvestigation of the spermatozoon ultrastructure of the cestode Proteocephalus longicollis (Zeder, 1800), a parasite of salmonid fish. Parasitology Research, 91, 357-362. DOI: 10.1007/s00436-0030977-4.

Bruňanská M., Scholz T., Nebesářová J. 2004a. Reinvestigation of spermiogenesis in the proteocephalidean cestode Proteocephalus longicollis (Zeder, 1800). Journal of Parasitology, 90, 23-29. DOI: 10.1645/GE-3229.

Caira J.N., Jensen K., Healy C.J. 1999. On the phylogenetic relationships among tetraphyllidean, lecanicephalidean and diphyllidean tapeworm genera. Systematic Parasitology, 42, 77-151. DOI: 10.1023/A:1006192603349.

Caira J.N., Mega J., Ruhnke T.R. 2005. An unusual blood sequestering tapeworm (Sanguilevator yearsleyi n. gen., n. sp.) from Borneo with description of Cathetocephalus resendezi n. sp. from Mexico and molecular support for the recognition of the order Cathetocephalidea (Platyhelminthes: Eucestoda). International Journal for Parasitology, 35, 1135-1152. DOI: 10.1016/j.ijpara.2005.03.014.

Euzet L. 1994. Order Tetraphyllidea. In: (Eds. L.F. Khalil, A. Jones and R.A. Bray) Keys to the cestode parasites of vertebrates. CAB International, Wallingford, UK, 149-194.

Euzet L., Świderski Z., Mokhtar-Maamouri F. 1981. Ultrastructure comparée du spermatozoïde des Cestodes. Relations avec la phylogénèse. Annales de Parasitologie (Paris), 56, 247-259.

Gamil I.S. 2008. Ultrastructural studies of the spermatogenesis and spermiogenesis of the caryophyllidean cestode Wenyonia virilis (Woodland, 1923). Parasitology Research, 103, 777-785. DOI: $10.1007 / \mathrm{s} 00436-008-1040-2$.

Hoberg E.P., Gardner S.L., Campbell R.A. 1999. Systematics of the Eucestoda: advances toward a new phylogenetic paradigm, and observations on the early diversification of tapeworms and vertebrates. Systematic Parasitology, 42, 1-12. DOI: 10.1023/A:1006099009495.

Hoberg E.P., Mariaux J., Brooks D.R. 2001. Phylogeny among orders of the Eucestoda (Cercomeromorphae): Integrating morphology, molecules and total evidence. In: (Eds. D.T.J. Littlewood and R.A. Bray) Interrelationships of the Platyhelminthes. Taylor and Francis, London, 112-126.

Hoberg E.P., Mariaux J., Justine J.-L., Brooks D.R., Weekes P.J. 1997. Phylogeny of the orders of the Eucestoda (Cercomeromorphae) based on comparative morphology: historical perspectives and a new working hypothesis. Journal of Parasitology, 83, 1128-1147.

Justine J.-L. 1986. Ultrastructure of the spermatozoon of the cestode Duthiersia fimbriata (Pseudophyllidea, Diphyllobothriidae). Canadian Journal of Zoology, 64, 1545-1548.

Justine J.-L. 1991. Phylogeny of parasitic Platyhelminthes: a critical study of synapomorphies proposed on the basis of the ultrastructure of spermiogenesis and spermatozoa. Canadian Journal of Zoology, 69, 1421-1440.

Justine J.-L. 1995. Spermatozoal ultrastructure and phylogeny of the parasitic Platyhelminthes. Mémoires du Muséum National d'Histoire Naturelle, Paris, 166, 55-86.

Justine J.-L. 1998. Spermatozoa as phylogenetic characters for the Eucestoda. Journal of Parasitology, 84, 385-408. DOI: $10.2307 / 3284502$.

Justine J.-L. 2001. Spermatozoa as phylogenetic characters for the Platyhelminthes. In: (Eds. D.T.J. Littlewood and R.A. Bray) Interrelationships of the Platyhelminthes. Taylor and Francis, London, 231-238.

Levron C., Bruňanská M., Kuchta R., Freeman M., Scholz T. 2006b. Spermatozoon ultrastructure of the pseudophyllidean cestode
Paraechinophallus japonicus, a parasite of deep-sea fish Psenopsis anomala (Perciformes, Centrolophidae). Parasitology Research, 100, 115-121. DOI: 10.1007/s00436-0060224-X.

Levron C., Bruňanská M., Marchand B. 2005. Spermiogenesis and sperm ultrastructure of the pseudophyllidean cestode Triaenophorus nodulosus (Pallas, 1781). Parasitology Research, 98, 26-33. DOI: 10.1007/s00436-005-0009-7.

Levron C., Bruňanská M., Poddubnaya L.G. 2006a. Spermatological characters in Diphyllobothrium latum (Cestoda, Pseudophyllidea). Journal of Morphology, 267, 1110-1119. DOI: 10. 1002/jmor. 10460.

Levron C., Bruňanská M., Poddubnaya L.G. 2006c. Spermatological characters of the pseudophyllidean cestode Bothriocephalus scorpii (Muller, 1781). Parasitology International, 55, 113120. DOI: 10.1016/j.parint.2005.11.055

Levron C., Miquel J., Oros M., Scholz T. 2010. Spermatozoa of tapeworms (Platyhelminthes, Eucestoda): advances in ultrastructural and phylogenetic studies. Biological Reviews, 85, 523-543. DOI: 10.1111/j.1469-185X.2009.00114.x.

Levron C., Sítko J., Scholz T. 2009. Spermiogenesis and spermatozoon of the tapeworm Ligula intestinalis (Diphyllobothriidea): phylogenetic implications. Journal of Parasitology, 95, 1-9. DOI: 10.1645/GE-1646.1.

MacKinnon B.M., Burt M.D.B. 1984. The comparative ultrastructure of spermatozoa from Bothrimonus sturionis Duv. 1842 (Pseudophyllidea), Pseudanthobothrium hanseni Baer, 1956 (Tetraphyllidea), and Monoecocestus americanus Stiles, 1895 (Cyclophyllidea). Canadian Journal of Zoology, 62, 10591066.

Mahendrasingam S., Fairweather I., Halton D.W. 1989. Spermatogenesis and the fine structure of the mature spermatozoon in the free proglottis of Trilocularia acanthiaevulgaris (Cestoda, Tetraphyllidea). Parasitology Research, 75, 287-298. DOI: 10.1007/BF00931813.

Marigo A.M., Świderski Z., Bâ C.T., Miquel J. 2011. Spermiogenesis and ultrastructure of the spermatozoon of the trypanorhynch cestode Aporhynchus menezesi (Aporhynchidae), a parasite of the velvet belly lanternshark Etmopterus spinax (Elasmobranchii: Etmopteridae). Folia Parasitologica, in press.

Miquel J., Eira C., Świderski Z., Conn D.B. 2007b. Mesocestoides lineatus (Goeze, 1782) (Mesocestoididae): new data on sperm ultrastructure. Journal of Parasitology, 93, 545-552. DOI: 10.1645/GE-1008R.1.

Miquel J., Feliu C., Marchand B. 1999. Ultrastructure of spermiogenesis and the spermatozoon of Mesocestoides litteratus (Cestoda, Mesocestoididae). International Journal for Parasitology, 29, 499-510. DOI: 10.1016/S0020-7519(98)00202-1.

Miquel J., Świderski Z. 2006. Ultrastructure of the spermatozoon of Dollfusiella spinulifera (Beveridge and Jones, 2000) Beveridge, Neifar and Euzet, 2004 (Trypanorhyncha, Eutetrarhynchidae). Parasitology Research, 99, 37-44. DOI: 10. 1007/s00436-005-0094-7.

Miquel J., Świderski Z., Neifar L., Eira C. 2007a. Ultrastructure of the spermatozoon of Parachristianella trygonis Dollfus, 1946 (Trypanorhyncha, Eutetrarhynchidae). Journal of Parasitology, 93, 1296-1302. DOI: 10.1645/GE-1193.1.

Mokhtar-Maamouri F. 1979. Étude en microscopie électronique de la spermiogenèse et du spermatozoïde de Phyllobothrium gracile Wedl, 1855 (Cestoda, Tetraphyllidea, Phyllobothriidae). Zeitschrift für Parasitenkunde, 59, 245-258. DOI: 10.1007/BF00927519.

Mokhtar-Maamouri F. 1982. Étude ultrastructurale de la spermiogenèse de Acanthobothrium filicolle var. filicolle Zschokke, 1888 (Cestoda, Tetraphyllidea, Onchobothriidae). Annales de Parasitologie (Paris), 57, 429-442. 
Mokhtar-Maamouri F., Świderski Z. 1975. Étude en microscopie électronique de la spermatogénèse de deux Cestodes Acanthobothrium filicolle benedeni Loennberg, 1889 et Onchobothrium uncinatum (Rud., 1819) (Tetraphyllidea, Onchobothriidae). Zeitschrift für Parasitenkunde, 47, 269-281. DOI: 10.1007/BF00389886.

Olson P.D., Littlewood D.T.J., Bray R.A., Mariaux J. 2001. Interrelationships and Evolution of the Tapeworms (Platyhelminthes: Cestoda). Molecular Phylogenetics and Evolution, 19, 443467. DOI: 10.1006/mpev.2001.0930.

Quilichini Y., Foata J., Bâ C.T., Marchand B. 2007. Ultrastructure of the spermatozoon of Calliobothrium verticillatum (Cestoda, Tetraphyllidea, Oncobothriidae). Acta Parasitologica, 52, 219-224. DOI: 10.2478/s11686-007-0037-9.

Schmidt G.D., Beveridge I. 1990. Cathetocephalus australis n. sp. (Cestoidea: Cathetocephalidae) from Australia, with a proposal for Cathetocephalidea n. ord. Journal of Parasitology, 76, 337-339.

Sène A., Bâ C.T., Marchand B. 1999. Ultrastructure of spermiogenesis of Phyllobothrium lactuca (Cestoda, Tetraphyllidea, Phyllobothriidae). Folia Parasitologica (Praha), 46, 191-198.

Šípková L., Levron C., Freeman M., Scholz T. 2010. Spermiogenesis and spermatozoon of the tapeworm Parabothriocephalus gracilis (Bothriocephalidea): Ultrastructural and cytochemi- cal studies. Acta Parasitologica, 55, 58-65. DOI: 10.2478/ s11686-010-0003-9.

Šípková L., Levron C., Oros M., Justine J.-L. 2011. Spermatological characters of bothriocephalideans (Cestoda) inferred from an ultrastructural study on Oncodiscus sauridae and Senga sp. Parasitology Research, in press. DOI: 10.1007/s00436-0102215-1.

Świderski Z., Mokhtar-Maamouri F. 1980. Étude de la spermatogénèse de Bothriocephalus clavibothrium Ariola, 1899 (Cestoda: Pseudophyllidea). Archives de l'Institut Pasteur de Tunis, 57, 323-347.

Thiéry J.P. 1967. Mise en évidence des polysaccharides sur coupes fines en microscopie électronique. Journal of Microscopy, 6 , 987-1018

Waeschenbach A., Webster B.L., Bray R.A., Littlewood D.T.J. 2007. Added resolution among ordinal level relationships of tapeworms (Platyhelminthes: Cestoda) with complete small and large subunit nuclear ribosomal RNA genes. Molecular Phylogenetics and Evolution, 45, 311-325. DOI: 10.1016/ j.ympev.2007.03.019.

Yoneva A., Levron C., Oros M., Orosová M., Scholz T. 2011. Ultrastructure of spermiogenesis and mature spermatozoon of Breviscolex orientalis (Cestoda: Caryophyllidea). Parasitology Research, in press. DOI: 10.1007/s00436-010-2144-z. 